\title{
CAUSE OF WITHERING OF STAGHORN SUMACH (RHUS TYPHINA L.) IN SELECTED LOCALITIES IN SLOVAKIA
}

\author{
GABRIELA JUHÁSOVÁ ${ }^{1}$, KATARÍNA ADAMČÍKOVÁ ${ }^{1}$, \\ MAREK KOBZA ${ }^{1}$, ANDREA ČEREVKOVÁ ${ }^{2}$ \\ ${ }^{1}$ Institute of Forest Ecology SAS, \\ Branch of Woody Plant Biology Nitra \\ Akademická 2, 94901 Nitra, Slovakia \\ ${ }^{2}$ SAU Department of Plant Protection \\ Tr. A. Hlinku 2, 94901 Nitra, Slovakia \\ e-mail: nruejuha@savba.sk
}

(Received: March 8, 2004. Accepted: November 11, 2004)

\begin{abstract}
Health state of Rhus typhina was evaluated in 59 localities and 74 sites over the years 2001-2003 with scope (1) to identify the parasitic mycoflora of $R$. typhina in Slovakia and (2) to identify the occurrence of Cryphonectria parasitica, declared as an quarantine pest by the EPPO, besides the chestnut (Castanea sativa Mill.) and oak (Quercus sp.) also on R. typhina. The fungus Botryosphaeria ribis (Gross.) Dugg. (pycnidial state Dothiorella mali (Ell.) Ev) caused damage to the R. typhina. Damage to $R$. typhina caused by B. ribis was only recorded in 15 localities. Mean growth rate of hyphae of the fungus ranged from 25.7 to $48.3 \mathrm{~mm}$ after 96 hours of cultivation. The most appropriate medium for cultivation was $3 \%$ potato dextrose agar.

The occurrence of the fungus Fusarium oxysporum Schlecht and mainly of quarantine fungus C. parasitica has not been recorded in the evaluated sites.
\end{abstract}

KEY WORDS: Botryosphaeria ribis, Cryphonectria parasitica, Fusarium oxysporum, Rhus typhina.

\section{INTRODUCTION}

Dieback of the ornamental tree Rhus typhina L. in consequence of infection with the fungus Botryosphaeria ribis Gross (Dugg.) (teleomorph) - pycnidium state (anamorph) Dothiorella mali (Ell.) Ev has been recorded in several localities in Slovakia. The fungus occurs in Slovakia since 1981, however, this fact has not yet been documented with detailed studies (Juhásová 1986).

Really dangerous pathogens of the R. typhina disease are the fungi Fusarium oxysporum Schlecht., B. ribis and Endothia parasitica syn. Cryphonectria parasitica (Murr.) Barr in North America (Toole 1949; Bragonier 1949). The fungus $F$. oxysporum has caused damage with symptoms of drying branches to other host trees in North America and Great Britain. C. parasitica, the chestnut blight fungus, was found on R. typhina in USA (Peace 1962). R. typhina is one of the many hosts of $C$. parasitica (Stipes et al. 1978). The fungus $C$. parasitica destroyed a whole plantation of R. typhina on which the plant was cultivated to obtain tannin (Př́íhoda 1999).

The goals of this research were (1) to establish the parasitic mycoflora of $R$. typhina in Slovakia and (2) to establish the occurrence of $C$. parasitica, declared as an qua- rantine pest by the EPPO, besides chestnut (Castanea sati$v a$ Mill.) and oak (Quercus sp.) on R. typhina.

\section{MATERIALS AND METHODS}

The health state of $R$. typhina was evaluated over the years 2000-2002 in Nitra and in selected localities in Slovakia. The list of the evaluated localities is presented in Table 1 .

The general health state was assessed in localities. The degree of damage to trees was evaluated according to a six-point scale:

$\mathrm{h}$ - healthy: without symptoms of disease;

1-st degree: rare occurrence of branches with thinned leaves;

2-nd degree: dry, thin branches in number 1-15 per one plant, no visible wounds on trunk;

3-rd degree: dry, thin branches, sharing $1 / 3$ in volume. Dripping wounds in size up to $2-3 \mathrm{~cm}$ on trunk;

4-th degree: drying branches in $1 / 2$ crown volume caused by fungus $B$. ribis. Damage of main and constructive branches is dominant. Dripping wounds on trunk, in size up to $5 \mathrm{~cm}$; 
TABLE 1. Results of evaluation of occurrence of Rhus typhina and degree of damage caused by fungus Botryosphaeria ribis in selected localities in Slovakia.

\begin{tabular}{|c|c|c|c|}
\hline $\begin{array}{l}\text { Number } \\
\text { of locality }\end{array}$ & Name of localities & $\begin{array}{c}\text { Degree } \\
\text { of damage }\end{array}$ & $\begin{array}{c}\text { Number } \\
\text { of trees }\end{array}$ \\
\hline 1 & Arborétum Mlyňany & $1-5$ & 25 \\
\hline 2 & Behynce & $\mathrm{h}$ & 5 \\
\hline 3 & Bošany & $\mathrm{h}$ & 2 \\
\hline 4 & Bratislava & $h-5$ & 21 \\
\hline 5 & Brodzany & $\mathrm{h}$ & 2 \\
\hline 6 & Bytča & $1-5$ & 5 \\
\hline 7 & Dubnica nad/Váhom & $\mathrm{h}$ & 3 \\
\hline 8 & Galanta & $1-5$ & 8 \\
\hline 9 & Jasov & $\mathrm{h}$ & 7 \\
\hline 10 & Jelenec & $1-2$ & 2 \\
\hline 11 & Jelšovce & $\mathrm{h}$ & 2 \\
\hline 12 & Turčianské Klačany & $\mathrm{h}$ & 2 \\
\hline 13 & Klačno & $1-3$ & 5 \\
\hline 14 & Kočkovce & $\mathrm{h}$ & 5 \\
\hline 15 & Komárno & $1-3$ & 8 \\
\hline 16 & Košeca & $\mathrm{h}$ & 2 \\
\hline 17 & Košice & $\mathrm{h}$ & 10 \\
\hline 18 & Kotešová & $\mathrm{h}$ & 2 \\
\hline 19 & Krušovce & $\mathrm{h}$ & 1 \\
\hline 20 & Ladce & $\mathrm{h}$ & 2 \\
\hline 21 & Tunežice & $\mathrm{h}$ & 5 \\
\hline 22 & Lietavská Lúčka & $\mathrm{h}$ & 1 \\
\hline 23 & Lučenec & $\mathrm{h}$ & 2 \\
\hline 24 & Ludanice & $\mathrm{h}$ & 1 \\
\hline 25 & Malé Uherce & $\mathrm{h}$ & 5 \\
\hline 26 & Malý Šariš & $\mathrm{h}$ & 5 \\
\hline 27 & Martin & $\mathrm{h}$ & 8 \\
\hline 28 & Medzev & $\mathrm{h}$ & 5 \\
\hline 29 & Moldava nad Bodvou & $\mathrm{h}$ & 5 \\
\hline 30 & Modra & $\mathrm{h}$ & 3 \\
\hline 31 & Myjava & $\mathrm{h}$ & 5 \\
\hline 32 & Nedožery-Brezany & $\mathrm{h}$ & 2 \\
\hline 33 & Nitra & $h-5$ & 89 \\
\hline 34 & Nováky & $\mathrm{h}$ & 2 \\
\hline 35 & Nové Mesto nad/Váhom & $\mathrm{h}$ & 5 \\
\hline 36 & Nové Zámky & $\mathrm{h}$ & 8 \\
\hline 37 & Oslany & $\mathrm{h}$ & 1 \\
\hline 38 & Ožd’any & $\mathrm{h}$ & 8 \\
\hline 39 & Pezinok & $1-5$ & 9 \\
\hline 40 & Piešt’any & $\mathrm{h}$ & 5 \\
\hline 41 & Poluvsie & $\mathrm{h}$ & 2 \\
\hline 42 & Považská Bystrica & $\mathrm{h}-1$ & 15 \\
\hline 43 & Prešov & $\mathrm{h}$ & 10 \\
\hline 44 & Prievidza & $\mathrm{h}$ & 2 \\
\hline 45 & Radošina & $\mathrm{h}-1$ & 5 \\
\hline 46 & Rajecké Teplice & $\mathrm{h}$ & 12 \\
\hline 47 & Ripňany & $\mathrm{h}$ & 2 \\
\hline 48 & Rišňovce & $\mathrm{h}$ & 5 \\
\hline 49 & Strážská & $\mathrm{h}$ & 2 \\
\hline 50 & Svederník & $\mathrm{h}$ & 2 \\
\hline 51 & Sverepec & $\mathrm{h}$ & 3 \\
\hline 52 & Chminianska Nová Ves & $\mathrm{h}$ & 10 \\
\hline 53 & Topol'̌̌any & $1-5$ & 15 \\
\hline 54 & Chrabrany & $\mathrm{h}$ & 2 \\
\hline 55 & Trenčín & $\mathrm{h}$ & 10 \\
\hline 56 & Výčapy & $\mathrm{h}$ & 3 \\
\hline 57 & Žabokreky & $\mathrm{h}$ & 1 \\
\hline 58 & Zemianske Kostolany & $\mathrm{h}$ & 1 \\
\hline 59 & Žilina & $1-5$ & 50 \\
\hline
\end{tabular}

h - healthy

$1-5$ degree of damage according to Materials and methods

5-th degree: the tree is totally dry or in very advanced drying stage, or dry branches comprise more than $2 / 3$ of crown in volume.
The following media were used for isolation and cultivation of the fungi (B. ribis and $C$. parasitica) sampled from R. typhina: 3\% Malt agar, 3\% Saccharose agar, 3\% Potato dextrose agar.

Growth rates of the hyphae of fungi were evaluated on three different media after each 24 hours of cultivation. The samples for measuring of growth rates were collected in Nitra at two different sites in October 1, 2002 and in Bytča in October 12, 2002. The fungus $C$. parasitica was isolated and cultivated according to Juhásová (1999).

The material for laboratory testing was sampled from shrubs with symptoms of damage. Pieces of bark, $2 \times 2 \mathrm{~cm}$ in size, were cut from the trunk and branches from:

- transition zone between health and infected part,

- reproductive bodies of fungus (pycnidium and perithecium),

- mycelium of fungus,

- dripping wound.

Pieces of host tissues 2-3 mm large were placed into the medium after superficial sterilisation with $0.15 \% \mathrm{NaClO}$. The fungus was cultivated at a constant temperature between $24-25^{\circ} \mathrm{C}$.

\section{RESULTS}

The fungus $B$. ribis was for the first time recorded in Žilina (on 50 trees) in 1981. By the year 1992, were found five new localities in Slovakia (Bratislava (18 infected trees), Komárno (8 infected trees), Nitra (72 infected trees), Arborétum Mlyňany (25 infected trees), Galanta (8 infected trees). The health state of $R$. typhina was evaluated in 59 localities and 74 sites within the years 2001-2002 (Fig. 4 ). By the year 2003, the fungus B. ribis was recorded on further seven localities (Bytča, Jelenec, Klačno, Pezinok, Považská Bystrica, Radošina, Topol’čany). 228 trees of $R$. typhina from a total number of 445 evaluated in Slovakia were damaged by $B$. ribis. The results of evaluation of the damage degree to $R$. typhina are shown in Table 1 .

The fungus $B$. ribis attacks various species of genus Ribis and it can cause serious damage of branches to $R$. typhina. The first symptoms of the disease occur in the phenological phase as complete leaf unfolding (Fig. 1). The leaves lose step by step their natural green colour, wither and very rapidly dry. Not only leaves do wither, but also terminal sprouts. The drying proceeds so rapidly that the leaves do not fall down, the ends of the damaged branches seem to be broke. It is conspicuous that the damaged parts maintain hanging on branches. Dry leaves remain on branches, too. The mycelium of the fungus penetrates from the terminal branches to the older parts. Whole branches dry out in the second year of infection. On bark surface a depression arises. The bark on stronger branches dries out and cracks, open blight cankers arise and frequently reach the xylem. Blight cankers fuse together, reaching the final dimensions up to $50 \mathrm{~mm}$. The bark around the blight cankers is coloured red to violet. Black stromata that penetrate through the periderm are very well visible with a magnifying glass. The fungus causes also damage to very young and older shrubs.

Pycnidia of the fungus usually germinate at the end of July (Fig. 2). They are well visible by naked eye, browncoloured, arranged concentrically on the necrotised part of 

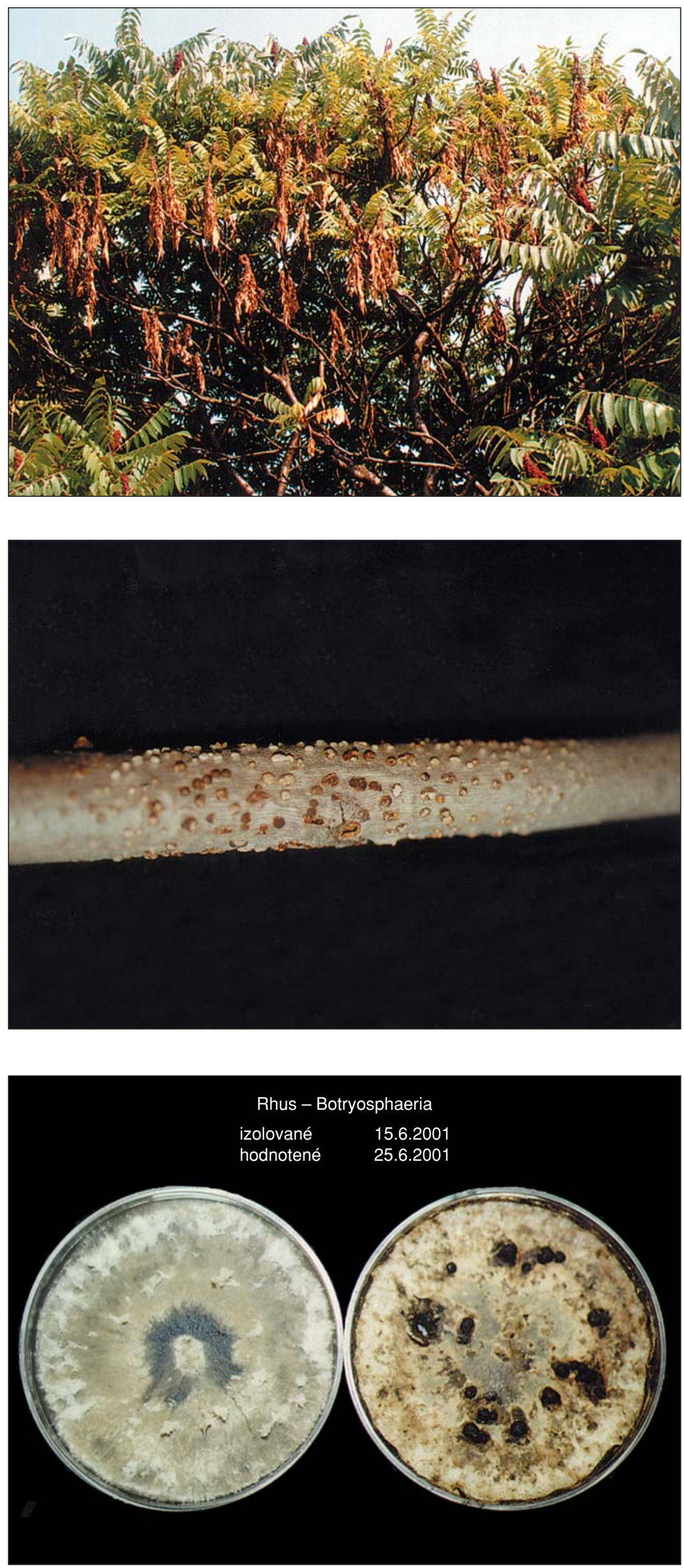

Fig. 1. Rhus typhina in Bratislava (Patrónka, SAS) damaged with the fungus Botryosphaeria ribis Gross (Dugg.) - pycnidial state anamorpha Dothiorella mali (Ell.) Ev. The damage to Rhus typhina significantly apprears in phenological phase complete leaf unfolding. The leaves and terminal parts of branches wither and very rapidly dry. The damaged parts maintain hanging on branches (August 8, 2003).

Fig. 2. Pycnidial fruiting bodies of the fungus Botryosphaeria ribis Gross (Dugg.) - pycnidial state anamorpha Dothiorella mali (Ell.) Ev. They are well visible by naked eye, 2-4 mm large, arranged concentrically on the necrotised part of the branch, white or light-brown coloured, later in germination browncoloured.

Fig. 3. Isolate of the fungus Botryosphaeria ribis Gross (Dugg.) on 3\% malt agar after 10 days of cultivation are formed dark fruiting bodies with pycnospores. 


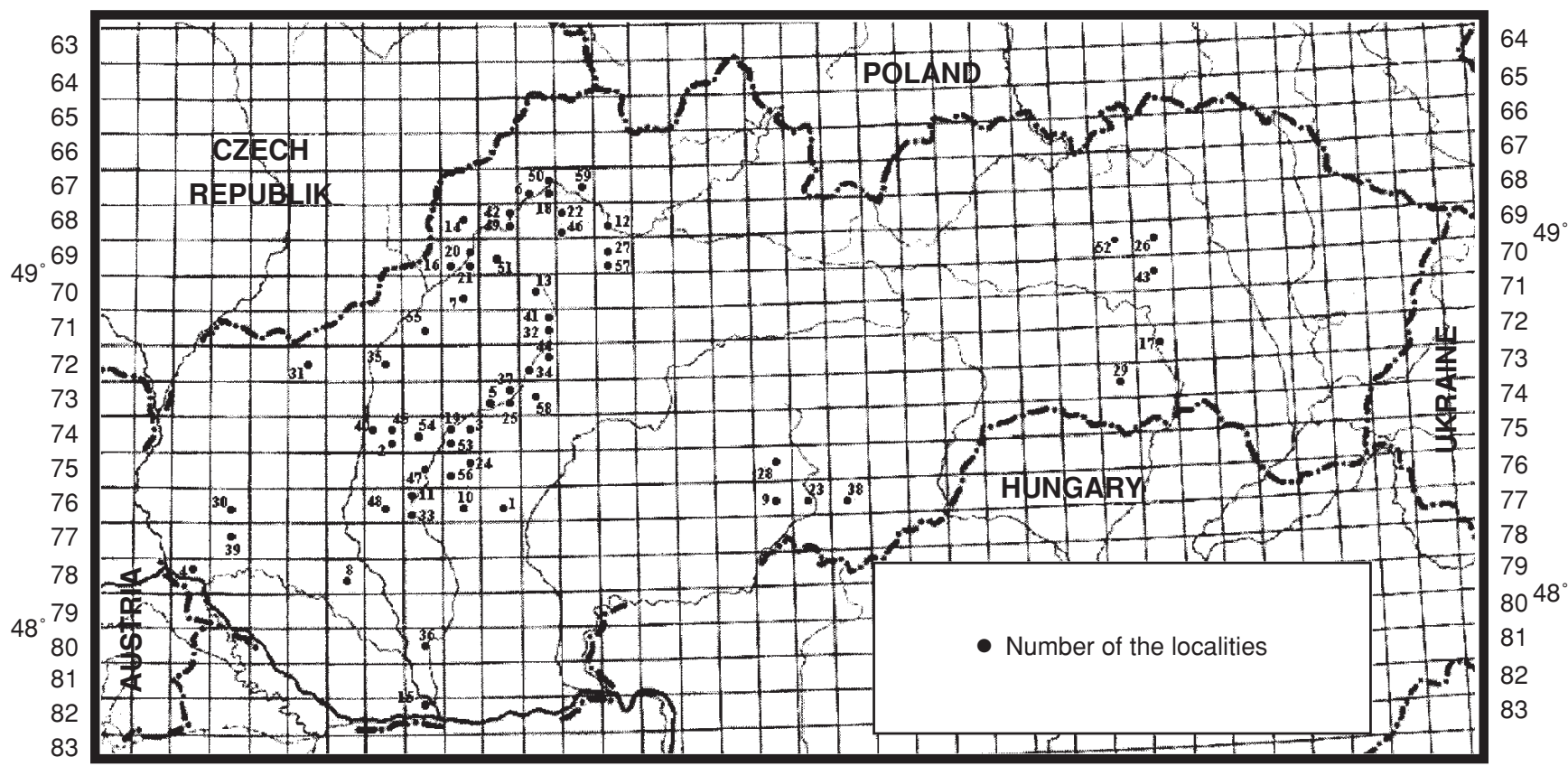

6667686970717273747576777879808182838485868788899091929394959697989900 17

Fig. 4. Map of Rhus typhina occurrence in selected localities in Slovakia. The numbers in the map correspond with number of localities in Table 1.

the branch. Pycnospores are hyaline, one-celled, 18-34×4-9 $\mu \mathrm{m}$ in size. Asci are $75-130 \times 19-21 \mu \mathrm{m}$ large. One ascus contains eight ascospores $(17-25 \times 5-8 \mu \mathrm{m})$. The fungus is a wound pathogen. The spores are spread by air, wind and water. The literature refers about insect of the genus Psenococus as a vector of this fungus. In our conditions, ascospores are spread to the end of April. Conidia are spread during the season.

The isolates of the fungus $B$. ribis were obtained in the conidial state $D$. mali. The isolation was successful on all used media (Fig. 3). The results of evaluation of growth rate are in Table 2.

The mean growth rate of hyphae of the fungus ranged from 25.7 to $48.3 \mathrm{~mm}$ after 96 hours of cultivation. The most appropriate medium for cultivation was $3 \%$ potato dextrose agar. The least suitable was saccharose agar, because no increase in mycelium length after first 48 hours could be recorded.

Symptoms of infection with the fungus $C$. parasitica were not present on shrubs in the observed localities. Mycelium of the fungus is yellow-coloured, fan-shaped and is located under the bark of the host woody plant. The fungus produces both red-orange pycnidia and perithecia of the sa-

TABLE 2. Length (in mm) of hyphae of fungus Botryosphaeria ribis on different media at 24 hours intervals.

\begin{tabular}{lccccc}
\hline \multirow{2}{*}{ Medium } & \multicolumn{5}{c}{ Mycelium length } \\
& \multicolumn{4}{c}{ at the end of cultivation interval (in hours) } \\
\cline { 2 - 7 } & $24 \mathrm{~h}$ & $48 \mathrm{~h}$ & $72 \mathrm{~h}$ & $96 \mathrm{~h}$ & average \\
\hline Malt agar & 12.5 & 33.6 & 48.6 & 63.3 & $\mathbf{3 9 . 5}$ \\
Saccharose agar & - & - & 15.6 & 35.8 & $\mathbf{2 5 . 7}$ \\
Potato dextrose agar & 9.3 & 36.9 & 67 & 80 & $\mathbf{4 8 . 3}$
\end{tabular}

me colour. Neither mycelium nor stromata of reproductive bodies of this internationally recognized quarantine pest were recorded on drying branches of $R$. typhina.

\section{DISCUSSION}

The fungus $B$. ribis cause damage to $R$. typhina shrubs. The fungus $F$. oxysporum and quarantine pest $C$. parasitica were not detected in the studied localities within the year 2003.

Toole (1949), Bragonier (1949) identified the fungi $F$. oxysporum, B. ribis and E. parasitica syn. $C$. parasitica as really dangerous pathogens of $R$. typhina disease. The health state in this shrub was evaluated in total at 74 sites on 59 localities. No occurrence of the fungus B. ribis was detected over the evaluated sites. The damage to $R$. typhina caused by $B$. ribis was only recorded in 13 localities.

Neither occurrence of the fungus $F$. oxysporum Schlecht and nor of the quarantine fungus $C$. parasitica was recorded over the evaluated sites. The fungus $C$. parasitica was detected in Slovakia, but on other host trees, on Castanea sativa and on Quercus sp. (Juhásová 1999).

The optimum temperature range for germination of ascospores is $12-15^{\circ} \mathrm{C}$ and the optimum temperature for mycelium growth in the fungus $B$. ribis is $28^{\circ} \mathrm{C}$ (Savanasto 1932).

The appropriate media for cultivation of this fungus are agar media with different ingredients (Savanasto 1932). We used 3\% Malt agar, 3\% Saccharose agar and 3\% Potato dextrose agar for isolation and cultivation of the fungus $B$. ribis at a temperature $24-25^{\circ} \mathrm{C}$. We have concluded that the worst medium for cultivation of this fungus was the Saccharose agar, because no growth of hyphae was observed during the first 48 hours of cultivation. 
The optimum temperature for mycelium growth on artificial media was detected as $28^{\circ} \mathrm{C}$, the minimum $10^{\circ} \mathrm{C}$ and the maximum $32^{\circ} \mathrm{C}$. The cultures were kept viable at a temperature of about $0^{\circ} \mathrm{C}$ for more than 22 months (Savanasto 1932).

\section{CONCLUSIONS}

Benčat' (1982) recorded the occurrence of Rhus typhina in 119 localities in Slovakia. The health state, with regard to the occurrence of quarantine fungus Cryphonectria parasitica and Botryosphaeria ribis, was assessed on 59 localities over the years 2001-2004. C. parasitica has not been recorded. B. ribis was isolated from 13 localities. This fungus causes serious damage of this ornamental tree that proves like drying of damaged branches after first year of infection. It is recommended to remove the damaged parts of host due to eliminate the source of infection.

\section{ACKNOWLEGMENT}

This research was supported by VEGA grant \# 2/4020/04.

\section{LITERATURE CITED}

BENČAŤ F. 1982. Atlas rozšírenia cudzokrajných drevín na Slovensku a rajonizácia ich pestovania. $359 \mathrm{pp}$. Veda Press of SAS, Bratislava, Slovakia. (in Slovak with English and Russian summary)

BRAGONIER W.H. 1949. Umbrella disease of Rhus glabra and $R$. typhina caused by Botryosphaeria ribis. Phytopathology 39: 3 .

JUHÁSOVÁ G. 1999. Hubové choroby gaštana jedlého (Castanea sativa Mill.). 98 pp. Veda Press of SAS, Bratislava, Slovakia. (in Slovak with English summary)

JUHÁSOVÁ G. 1986. Výsledky fytopatologického výskumu drevín v Arboréte Mlyňany. Forestry 32, 8: 505-514. (in Slovak)

PEACE T.R. 1962. Pathology of trees and shrubs. 753 pp. Oxford University Press, London, GB.

Př́́HODA A. 1999. Kaštanovník jedlý jako lesní drevina i pro zver. Myslivost. XLVII, 11. (in Slovak)

SAVASTANO G. 1932. Una gummosi del limone causata da Dothiorella. Boll. r. staz. pat. veget. N. S. 12: 245-274.

STIPES R.J., HUNTER P.P., ELKINS J.R., ROANE M.K. 1978. Endothia cankers of oaks. Metro Tree Impr. Alliance (Metria) Proc. 1: 97-120.

TOOLE E.R. 1949. Fusarium wilt of Staghorn Sumach. Phytopathology 39: 754-759. 